\title{
Modeling the Impact of Social Transfers on the Inequality of Income Distribution in Society
}

\author{
Oksana Bashutska \\ Department of Economic Cybernetics \\ and Informatics \\ Ternopil National Economic University \\ Ternopil, Ukraine \\ o.bashutska@gmail.com \\ Oksana Bodnar \\ Department of Pedagogy and \\ Educational Management \\ Volodymyr Gnatiuk Ternopil National \\ Pedagogical University \\ Ternopil, Ukraine \\ bodnarotern@ukr.net
}

\author{
Lesia Buiak \\ Department of Economic Cybernetics \\ and Informatics \\ Ternopil National Economic University \\ Ternopil, Ukraine \\ lesyabuyak@ukr.net
}

\author{
Mykola Shynkaryk \\ Department of Applied Mathematics \\ Ternopil National Economic University \\ Ternopil, Ukraine \\ shynkaryk_m@ukr.net
}

\begin{abstract}
The impact of social transfers on income inequality in society is analyzed. The role of social transfers in redistributing income and reducing the level of differentiation of society is revealed. The choice of the total income components for all types of social transfers is substantiated. An algorithm for applying the Gini-Taylor coefficient to decompose inequalities by components of total income is constructed. The decomposition of the Gini-Tyla coefficient into components by source of income is performed. Concentration ratios, absolute and relative contributions were calculated for the 11 selected income components based on the total household income of Ukraine in 2018. Ways of improvement of social protection of the population with the purpose of overcoming inequality of distribution of incomes in a society are offered. When modeling the impact of different types of social transfers on income inequality in society, an effective method is to use the decomposition of the Gini coefficient. Similar calculations can be made both in dynamics and in countries, regions, etc. This will allow to analyze the effectiveness of social policy of the state.
\end{abstract}

Keywords - modeling, the social protection, transfer, decomposition.

\section{INTRODUCTION}

In the current conditions of development of sociallysecured market economy, the question of the functioning of the social sphere is a priority. The social sphere is the most diverse of the highest economies. Therefore, it is believed that the social organization is the harmonization of social relations, which supports all the necessary groups and there is a group of people engaged in sustainable human development, countering life and social responsibility, known decent life, social security, known social sphere: education, security issues, housing, communal services, culture, physical culture and sports [1].

Among the indicators that characterize the level of wellbeing, the most important are the income of the population, their dynamics and structure. Therefore, greater attention should be paid to increasing the incomes and protecting the socially vulnerable categories of citizens. This task can be partially solved by the redistribution of income in society. Social transfers are one of the tools of such redistribution. The system of social transfers is one of the prerequisites for ensuring social justice in society and maintains political stability. Excessive differentiation of household incomes is today the most acute problem for both Ukraine and a number of European countries.

At its core, social transfers are a system of monetary or in-kind payments to the public that are not related to its involvement in economic activity now or in the past.

The purpose of social transfers is to reduce the level of differentiation of income and social inequality. Social transfers include social benefits and other current transfers received by the population, namely: all types of pensions, scholarships, benefits and subsidies, benefits, health and treatment vouchers, charitable assistance, social services provided by non-governmental organizations, etc. In Ukraine, social transfers are provided in cash (cash and noncash) and in kind.

Today there is a problem of low impact of social transfers on restoration of well-being of vulnerable sections of the population, low degree of their targeting. And in some cases, social transfers have had a disincentive effect on the ablebodied population. The increase in social transfers did not significantly reduce the level of social delamination. All this indicates the need for more research in this area.

\section{STATEMENT OF THE PROBLEM}

One of the most important reasons for the ineffectiveness of social protection in Ukraine is the continuation of the practice of planning social expenditures on social protection while lowering social standards that take into account the possibilities of public finances, rather than the real need to finance social programs. The disadvantages of administering the social transfer system include the following:

- the inadequacy of the means of combating social assistance in an illegal manner and through fraud; 
- discrepancy between the declared income and the real financial status of the family;

- a large amount of aid intended as an "exception";

- there is an imbalance in the structure of social transfers themselves, dominated by natural transfers, of which about $13 \%$ and social assistance - more than $50 \%$.

Researchers have repeatedly addressed the issues of research of theoretical provisions, mechanisms of functioning and problems of solving problems of financing the social sphere. The scientific works of the following researchers are devoted to these issues: D. Aschauer, R. Breuer, A. Gritsenko, B. Danylyshyn, J. Eliasson, H. Singer, S. Zlupko, T. Campbell, V. Krasovskyi, V. Kutsenko, E. Libanova, O. Makarova, O. Novikova, A. Pesenta, S. Pisarenko, U. Sadova, P. Syniayeva and others. In the scientific literature, considerable attention has been paid to the individual components of social transfers: social benefits, benefits, pensions, etc. Functional purpose, the role of social transfers in the system of social protection, the role of social transfers in the formation of aggregate household resources are considered in the works of O. Komarov, A. Melnyk, T. Kizima. M. Kholod studied the impact of social transfers on income inequality and poverty in transition economies [2]. However, the impact of social transfers on income inequality in society remains under-explored.

Inequality decomposition is a standard procedure that determines the contribution of each component to the overall inequality. This direction of research was initiated by $\mathrm{F}$. Borgunon, F. Cowell and A. Shorrox [3; 4; 5]. Improvements to this methodology were carried out by R. Lerman, S. Itzhaki, S. Jenkins, and A. Dayton $[6 ; 7 ; 8]$.

The purpose of the study is to analyze the impact of different types of social transfers on income inequality in society based on the decomposition of the Gini - Taylor coefficient.

For the analysis of inequality we define the structure of income. According to the purpose of the study, a structure of income should be identified, which would be detailed by the necessary components (in this case by the most detailed list of social transfers), while covering the main sources of household income. However, the detail is determined not only by the purpose of the research, but also by the capabilities of the information base.

The choice of components of total income depends on the following prerequisites:

1) it is necessary to take into account the main types of income (wages, pensions, income from business activities);

2) you need to find out the size and nature of the contribution to the inequality of different social transfers (all types of assistance, benefits, subsidies, etc.). They account for a small proportion of the total income structure, but decomposing inequalities we consider them in as much detail as possible to allow for the representativeness of the sample;

3 ) the specificity of generating the total income of many Ukrainian households is a significant role of monetary and non-monetary income from personal subsistence farming and assistance from relatives; therefore, it is important to identify their contribution to the overall inequality, despite the decline in these revenues in recent years.

Let us decompose the Gini coefficient into the following 11 components: remuneration; pensions; income from entrepreneurship and self-employment; help; subsidies; benefits; income from the sale of agricultural products; property income; financial assistance from relatives and others; the value of consumed products obtained from the private farm and from self-harvesting; other income.

In the aid structure, we distinguish the following types of assistance provided to the most vulnerable in order to determine the nature of their impact on general inequality:

- unemployment benefits;

- child support;

- assistance to needy families;

- other types of assistance.

Consider the algorithm and use of the formula for the decomposition of the Gini - Teil coefficient.

Decomposing inequalities by components of total income makes it possible to determine what types of income have a positive and negative effect on overall inequality, as well as the extent of this impact.

The Gini coefficient is given by the formula [10]:

$$
G=\frac{2}{S \cdot n^{2}} \cdot \sum_{i=1}^{N}\left(r_{i}-\frac{n+1}{2}\right) \cdot d_{i}
$$

where $S$ - is the average per capita amount of total income, $\mathrm{UAH} ; n-$ is the number of observations (population); $r_{i}-$ is the $i$-th rank of a household on an average income scale (the household with the lowest income will have $r_{i}=1$, and the lowest $\left.r_{i}=n\right) ; d_{i}-$ the average per capita total income of the $i$-th household.

The Gini Index can be broken down into components by revenue source. Each component of the Gini index is the product of the concentration ratio of the respective income component and the share of that component in the total income.

The concentration ratio for the $k$-th component of income is determined by the formula:

$$
G_{k}^{*}=\frac{2}{S_{k} \cdot n^{2}} \cdot \sum_{i=1}^{N}\left(r_{i}-\frac{n+1}{2}\right) \cdot p_{k i}
$$

where $S_{k}$ - average per capita size of the k-th component of income, UAH; $p_{k i}$ - components of $k$-th income and $i$-th household.

The sum of all components should be equal to the average per capita total household income:

$$
d_{i}=\sum_{i=1}^{K} p_{k i}
$$




\section{ESTIMATED COMPONENT OF THE STUDY}

The concentration coefficients for the income components are calculated in the following order:

1) for each household of the aggregate, the size of each income component is calculated;

2) for the whole population, the average per capita amount of this income component is calculated;

3) ranking all households by average per capita income so that the lowest-income household receives the lowest rank and the highest-income household receives the highest rank;

4) the decomposition of the Gini coefficient by sources of income and the calculation of each individual concentration coefficient always uses the ranks constructed to divide the total income;

5) the size of each household is subtracted, which is calculated as half the population increased by one. As a result, we obtain negative numbers for low-rank individuals and positive numbers for high-rank individuals;

6) the number obtained is multiplied by the size of the kth component of income of the respective household, the results are summed up over the whole population;

7) the amount received is multiplied by

$$
\frac{2}{S_{k} \cdot n^{2}}
$$

the result will be a concentration factor for the $k$-th component of income.

Multiply the concentration factor of the kth component of income by its share in the structure of total income, thus we obtain the value of the $k$-th component of income

$$
\frac{S_{k}}{S} \cdot G_{k}^{*}
$$

which reflects the absolute contribution of this component to the overall inequality. We find the Gini coefficient as the sum of these absolute contributions, or otherwise as a weighted sum of the concentration coefficients:

$$
G=\sum_{i=1}^{K} \frac{S_{k}}{S} \cdot G_{k}^{*}=\sum_{i=1}^{K} W_{k} \cdot G_{k}^{*}
$$

where $W_{k}=S_{k} / S$ - part of component $k$ in total income.

The percentage weight of the $k$-th component of income in aggregate income inequality is calculated as the ratio of the k-th component to the Gini coefficient:

$$
V_{k}=\frac{W_{k} \cdot G_{k}^{*}}{G} \cdot 100 \%
$$

The value of this expression shows the total weight of the income component $k$ among the inequality factors.

$$
\sum_{k=1}^{K} V_{k}=100 \%
$$

Based on the Household Living Survey data for 2018, we calculate the amounts of all types of income mentioned above, as well as their average per capita values and total income structure (Table 1).

Next, we rank all individuals by average per capita total income from smallest to largest. From the rank of each individual, subtract the number 22344359 received as a result of calculating the expression:

$$
\frac{42386427+1}{2}=21193214
$$

To calculate the concentration coefficient for the first component of total income (wage), we multiply the number by the amount of wages of each household and sum the results over the entire set, yielding $1.89 \cdot 10^{18}$.

Calculate the value of:

$$
\frac{2}{S_{k} \cdot n^{2}}=\frac{2}{5391.23 \cdot 42386427^{2}}=2.065 * 10^{-19}
$$

TABLE I. STRUCTURE OF TOTAL HOUSEHOLD INCOME OF UKRAINE IN 2018 [11]

\begin{tabular}{|l|l|l|}
\hline \multicolumn{1}{|c|}{ Components of total income } & \multicolumn{2}{|c|}{ Structure } \\
\cline { 2 - 3 } & \multicolumn{1}{|c|}{ грн } & \% \\
\hline Pay & 5391.23 & 55.46 \\
\hline Pensions and self- & 1734.42 & 17.84 \\
\hline $\begin{array}{l}\text { Income from entrepreneurship } \\
\text { employment }\end{array}$ & 592.77 & 6.10 \\
\hline Assistance, including: & 203.04 & 2.09 \\
\hline unemployment benefits & 13.93 & 0.14 \\
\hline help for children & 125.61 & 1.29 \\
\hline assistance to needy families & 18.44 & 0.19 \\
\hline other types of assistance & 37.95 & 0.39 \\
\hline Subsidies & 7.11 & 0.07 \\
\hline Benefits & 37.98 & 0.3 \\
\hline Proceeds from the sale of agricultural products & 248.40 & 2.56 \\
\hline Property income & 130.30 & 1.34 \\
\hline Cash assistance from relatives and caregivers & 399.21 & 4.11 \\
\hline $\begin{array}{l}\text { The cost of consumed products obtained from } \\
\text { the personal farm and self-procurement }\end{array}$ & 373.76 & 3.85 \\
\hline Other income & 406.09 & 4.2 \\
\hline Total & $\mathbf{9 7 2 0 . 2 4}$ & $\mathbf{1 0 0}$ \\
\hline
\end{tabular}

We obtain the value of the concentration coefficient for the first component of income - wages [12]:

$$
1.65 \cdot 10^{18} \cdot 2.06 \cdot 10^{-19}=0,33 \text { або } 33 \% \text {. }
$$

By dividing the coefficient of concentration of remuneration by the share of remuneration in the structure of total income, we get the absolute contribution of remuneration to the total inequality:

$$
\frac{33}{55.46} \cdot 33 \%=18.1 \% \text {. }
$$

The sum of the absolute contributions to the inequality of all components will be equal to the Gini coefficient $-26.8 \%$.

Similarly, calculate all other components of total income. The results obtained are presented in Table II. 
Identifying and decomposing by income sources is necessary to determine the impact of a particular income component $\mathrm{k}$ on overall differentiation, and how changes to a particular income source will affect overall income differentiation.

If the concentration factor of the income component $k$ is greater than the aggregate Gini coefficient, an increase in the source of income $k$ will lead to an increase in inequality. This is important when pursuing an income redistribution policy.

Based on the calculations, we can see that the concentration coefficient for such components of income as wages, income from business and self-conceit, benefits and other income exceed the Gini coefficient. Among social transfers, one should pay attention to such a component of total income as benefits, with a concentration ratio of $31.3 \%$.

TABLE II. PERCENTAGE CONTRIBUTION TO INEQUALITY OF CERTAIN COMPONENTS OF TOTAL INCOME

\begin{tabular}{|c|c|c|c|}
\hline Components of total income & $\begin{array}{l}\text { Concentration } \\
\text { factor, } \%\end{array}$ & $\begin{array}{c}\text { The absolute contribution to } \\
\text { inequality, } \%\end{array}$ & $\begin{array}{c}\text { The relative contribution to } \\
\text { inequality, } \%\end{array}$ \\
\hline Pay & 39.0 & 18.1 & 61.2 \\
\hline Pensions & 21.7 & 4.8 & 18.6 \\
\hline $\begin{array}{l}\text { Income from entrepreneurship and self- } \\
\text { employment }\end{array}$ & 45.4 & 2.4 & 9.5 \\
\hline Assistance, including: & -0.6 & 0 & 0 \\
\hline unemployment benefits & -16.9 & 0.01 & -0.1 \\
\hline help for children & -23.5 & -0.3 & -1.1 \\
\hline assistance to needy families & -68.6 & -0.1 & -0.2 \\
\hline other types of assistance & 32.9 & 0.4 & 1.5 \\
\hline Subsidies & -9.6 & 0.0 & -0.2 \\
\hline Benefits & 31.3 & 0.2 & 1.2 \\
\hline Proceeds from the sale of agricultural products & 8.3 & 0.2 & 1.3 \\
\hline Property income & 12.7 & 0.1 & 0.3 \\
\hline Cash assistance from relatives and caregivers & 23.6 & 1.1 & 4.2 \\
\hline $\begin{array}{l}\text { The cost of consumed products obtained from } \\
\text { the personal farm and self-procurement }\end{array}$ & -1.7 & -0.1 & -0.2 \\
\hline Other income & 31.3 & 1.2 & 4.0 \\
\hline Total & & 26.8 & 100 \\
\hline
\end{tabular}

\section{CONCLUSUION}

Based on the obtained results, we conclude that the main factor of inequality of total income is the wage component.This component explains about $61 \%$ of the Gini coefficient. Therefore, reforming the remuneration system is a key step in regulating cash income inequality. These reforms should aim at ensuring high pay. Social transfers also account for a large portion of total household income. Determining the size and distribution of social transfers between different social groups is the main task of the state's social policy. Among social transfers, a significant contribution to the Gini coefficient is made up of such a component of total income as pensions. They account for a significant portion $(17.84 \%)$ of total household income and are a major part of transfers. The relative contribution of pensions to the overall inequality in 2018 was $18.6 \%$. Another type of social transfers is benefits (unemployment, for children, low-income families). These components have downward effect on the inequality of income distribution in society. The contribution of this component to the Gini coefficient was negligible (about $-1.5 \%$ ). This shows that targeted social benefits reduce income differentiation. It is necessary to streamline all types of state social assistance and to refuse assistance to certain categories of the population and move on to the provision of targeted individual or family benefits (taking into account personal needs, financial status and living conditions). This will increase aid to the truly needy without significantly increasing overall budget expenditures. But it should be noted that social transfers in Ukraine still have little impact on overcoming income inequality in society. When modeling the impact of different types of social transfers on income inequality in society, an effective method is to use the decomposition of the Gini coefficient. Similar calculations can be made both in dynamics and in countries, regions, etc. This will allow to analyze the effectiveness of social policy of the state.

\section{REFERENCES}

[1] E. M. Libanova, and M. V. Ptukha, Social Outcomes of State Programs: Theoretical, Methodological and Applied Aspects of Evaluation. Uman: Publisher Sochi, 2012

[2] N. M. Kholod, Income sharing and poverty in transition economies L'viv:Vydavnychyy tsentr LNU im. Ivana Franka, 2016.

[3] F. Bourguignon, "Decomposable Income Inequality Measures", Econometrica, vol. 47, pp. 901-920, 1979.

[4] F.A. Cowell, "On the Structure of Additive Inequality Measures", Review of Economic Studies, vol. 47, pp. 521-531, 1980.

[5] A.F. Shorrocks, "The Impact of Income Components on the Distribution of Family Incomes", Quarterly Journal of Economics, no. 98, pp. 311-326, 1982.

[6] A. Deaton, The Analysis of Household Surveys: A Microeconometric Approach to Development Policy. Baltimore: The John Hopkins University Press, 1997.

[7] S.P. Jenkins, "Accounting for Inequality Trends: Decomposition Analyses for the UK" , Economica, no. 62, pp. 139-191, 1995.

[8] S. Yitzhaki, and R. Lerman, "Income Inequality Effects by Income Source: a New Approach and Applications to the United States", The Review of Income and Wealth, no. 37, pp. 313-329, 1991.

[9] N.Podder, and B. Tran-Nam, Uses and Abuses of the Decomposition of Gini Index by Factor Components. University of New South Wales, 1991.

[10] Turn reforms to the benefit of all and sundry. Poverty and inequality in Europe and Central Asia. - Washington, O.K .: World Bank, 2011.

[11] Expenditure and Resources of Households of Ukraine in 2018 year [Online]. Available: http://www.ukrstat.gov.ua/druk/publicat/kat u /2019/zb/06/zb_vrdu2018.pdf. Accessed on: July 10, 2019

[12] Social Protection of the Population of Ukraine: Statistical Yearbook, 2018. Kyiv: State Statistical Servise of Ukraine [in Ukrainian] 